\title{
Production of Dietetic Jam of Umbu-Caja (Spondias sp.): Physical, Physicochemical and Sensorial Evaluations
}

\author{
Maria Eugênia de Oliveira Mamede ${ }^{1}$, Leonardo Dib de Carvalho ${ }^{1}$, Eliseth de Souza Viana ${ }^{2}$, \\ Luciana Alves de Oliveira ${ }^{2}$, Walter dos Santos Soares Filho ${ }^{2}$, Rogério Ritzinger ${ }^{2}$ \\ ${ }^{1}$ Departamento de Análises Bromatológicas, Faculdade de Farmácia, Universidade Federal da Bahia, Salvador, Brazil; ${ }^{2}$ Embrapa \\ Mandioca e Fruticultura Tropical, Rua Embrapa s/n Bairro Chapadinha, Cruz das Almas, Brazil. \\ Email: mmamede2003@yahoo.com.br
}

Received February $3^{\text {rd }}, 2013$; revised March $1^{\text {st }}, 2013$; accepted March $8^{\text {th }}, 2013$

Copyright (C) 2013 Maria Eugênia de Oliveira Mamede et al. This is an open access article distributed under the Creative Commons Attribution License, which permits unrestricted use, distribution, and reproduction in any medium, provided the original work is properly cited.

\begin{abstract}
The umbucajazeira is specie native to the Brazilian Northeast semiarid areas, which is economically explored based on the fruit. The fruit has a high agroindustrial potential, mainly for jam production. The aim of this study was to evaluate through sensorial analysis, two formulations of umbu-caja jams: a dietetic one with xylitol, used as an option for substitution of the sugars, and a conventional one. The proportion of 50:50:0.5 (pulp/sugar/pectin or pulp/xylitol/pectin) was used for jam processing. The mixture was concentrated up to reach $65^{\circ}$ Brix. The jams were evaluated by 50 non-trained tasters, through a hedonic scale of nine points, whereas the following attributes were used: appearance, color, flavor, aroma and texture. The results of the physical and physicochemical analysis showed that the characteristics of jams prepared with sucrose are close to the ones made with xylitol, except for the total sugars and the energetic value. The jams had $\mathrm{pH}$ values ranging between 2.37 and 2.92; titratable acidity varying between 0.56 and $0.78 \mathrm{~g}$ citric acid $/ 100 \mathrm{~g}$ pulp; soluble solids ranging between $60.92^{\circ}$ and $65.08^{\circ}$ Brix, respectively. A tendency for yellow color was noticed by the color analysis. Jam diet had the highest scores for appearance (7.4 - 7.7). No significant differences $(p>$ 0.05 ) were obtained to flavor and texture. The fruit of the umbucajazeira showed to be adequate for jam manufature since they had good sensorial acceptance. The use of xylitol was satisfactory for obtaining a product with jam characteristics similar to the conventional jam, but with lower energetic value.
\end{abstract}

Keywords: Sensorial Acceptance; Jam Production; Umbucajazeira; Xylitol

\section{Introduction}

The umbu-caja is the fruit of the umbucajazeira (Spondias sp.) that belongs to the Anarcadiaceae family. The umbucajazeira is native to the semiarid areas of Northeast Brazil, found mainly throughout the states of Rio Grande do Norte, Ceará, Piauí, Pernambuco and Bahia [1,2]. The fruit has a prominent acid flavor, which limits its consumption as fresh fruit, with $\mathrm{pH}$ value varying between 2.4 and 3.0 [1].

Although it is an acidic fruit, the umbu-caja presents values of Soluble Solids ( ${ }^{\circ}$ Brix) of 9.1 for green pulp and 11.3 for ripe pulp. Furthermore, the fruit gives a pulp output of about $55 \%$ to $65 \%$, and therefore shows great potential for use as frozen pulp, juice, nectar and ice cream [3]. Due to the relatively high acidity, refreshing flavor and pleasant and exotic aroma, some authors consider this fruit suitable for manufacture of jam [4].
In 2008, Brazil exported $347.930 \mathrm{~kg}$ of jam, generating a market value of US\$739.961, meaning an increase of $83.5 \%$ in comparison to 2007 [5]. The tendency of the Brazilian market of jams is the release of this product with low sugar content and/or diet. Consumers are increasingly better informed about diet, and health, and as a result, desire more foods which offer, in addition to convenience, high quality, safety, optimum nutrient balance, less fat/cholesterol/sugar and fewer calories [6]. These products are gaining market share compared to the conventional jams (prepared with sucrose) since a portion of the population has restrictions to the consumption of sugar and therefore, the development of a suitable product for individuals in this category becomes necessary; substituting sucrose, for sweeteners. In this case, some sweeteners are used in the processing of jams, such as the sorbitol, mannitol, sucralose, acesulfame $\mathrm{K}$, sac- 
charin, aspartame, stevioside, cyclamate and xylitol [712].

The use of sweeteners in foods may not contemplate the expected sweetness by the consumer and still present an "aftertaste", which can damage the commercialization of the product, even for those who need products with caloric restriction. The consumers want a dietetic product with a pleasant flavor and similar to the conventional one. Xylitol, penta-hydroxylate alcohol, has been pointed out as an option for substitution of sugars due to its less caloric value, around $2.4 \mathrm{Kcalg}^{-1}$ [13] with sweetness power as same as sucrose [14]. This polyol presents some advantages, such as: not darkening through the Maillard reaction, having higher chemical stability, higher resistance to crystallization, higher affinity for water and smaller susceptibility for fermenting [15].

The objective of this work was to produce jam from two umbu-caja accessions in two ripening stages, in the dietetic and conventional forms, and to evaluate the physical, physicochemical and sensorial characteristics of these products.

\section{Material and Methods}

\subsection{Samples}

Fruit belonging to the accessions Preciosa and Suprema were collected at the "turning color" stage, in the city of Itaberaba, Bahia State, Brazil.

The fruit went through a first washing and pre-selection by immersion in three tanks filled with clean water. Afterwards, the fruit were hygienized in sodium hypochlorite solution in the concentration of $50 \mathrm{ppm}$ for 15 minutes. The fruit had the pulp removed in an industrial stripping machine, with $2.5 \mathrm{~mm}$ sieves, and frozen to $-18^{\circ} \mathrm{C}$. For obtaining the ripe pulp, part of the picked fruit were kept at room temperature $\left(25^{\circ} \mathrm{C} \pm 2{ }^{\circ} \mathrm{C}\right)$, in polyethylene trays, until they reached the ripe stage; characterized by the completely yellow skin color.

\subsection{Jam Processing}

In all the formulations, $50 \%$ sucrose or xylitol of the supplier Tovani Benzaquen Com. Imp. Exp. and Representações LTDA, 50\% pulp and $0.5 \%$ pectin GENU 105 of the trademark CP Kelco (high metoxilation content) was used, considering the total jam weight to be produced.

The pulp (green or ripe) mixed with sucrose or xylitol was concentrated up to $60^{\circ}$ Brix and added to the pectin, previously dissolved in hot water, at $80^{\circ} \mathrm{C}$. When the jam reached up to $65^{\circ}$ Brix, after approximately 30 minutes of cooking, the process was concluded. The jam was canned hot in $250 \mathrm{~g}$ glass containers, previously sterilized in water at $100^{\circ} \mathrm{C}$ for 30 minutes.

\subsection{Sensorial Analysis}

Initially 73 judges were recruited through an applied questionnaire, having as exclusion criteria, people that do not consume fruit jams, taking any type of medication that could interfere with the analysis, having diabetes or gastritis and being on food diet for health reasons.

The acceptance of the jams was evaluated as to appearance, color, aroma, flavor and texture by 50 jam consumers. A structured 9-point hedonic scale with extremes of "Dislike extremely" and "Liked extremely", was used. Also, the test of purchase intention was applied on the same days of the acceptance test. To evaluate purchasing intention a nominal five point scale was used ( 5 = "Definitely would not buy" and $1=$ "Definitely would buy") [16].

The eight jam samples were evaluated in two days. They were introduced to the consumers in $50 \mathrm{~mL}$ disposable cups identified with a 3 digit code along with water and salt crackers.

\subsection{Physicochemical Analyses}

The analyses of $\mathrm{pH}$, soluble solids (SS), titratable acidity (TA), humidity, ashes, protein and total lipids were accomplished according to the methodology described by the Institute Adolfo Lutz [17]. The contents of reduced sugars and total sugars were determined by the Somogyi and Nelson method $[18,19]$. The analysis was carried out in triplicates.

\subsection{Color Analysis}

The profile of the colors of the jams was determined by a Minolta colorimeter, model CR400, using illuminant D65. The coordinates $\mathrm{L}^{*}, \mathrm{a}^{*}, \mathrm{~b}^{*}, \mathrm{C}^{*}$ and $\mathrm{h}^{*}$, meaning brightness, green/red shade, blue/yellow shade, saturation and color angle, respectively, were measured in triplicates.

\subsection{Texture Analysis}

Texture was measured using a texture analysis equipment (Model: TAXT-plus-Stable Micro Systems, UK) with a flat bottom $(\varnothing 35 \mathrm{~mm})$ aluminum cylinder probe. An application study was used from the software that came with the equipment based on the comparison of firmness and consistency of hair gels. The compression was carried out at a pre-test speed of $1.5 \mathrm{~mm} / \mathrm{s}$; test speed at 2.0 $\mathrm{mm} / \mathrm{s}$ and post-test speed at $2.0 \mathrm{~mm} / \mathrm{s}$, with penetration distance of $20 \mathrm{~mm}$. For each sample, the firmness, maximum resistance force offered by the sample before rupture of the surface of the gel, in grams, and consistency, which represents the area in the graph in grams $\times$ seconds, were evaluated. The analysis was carried out in triplicates. 


\subsection{Cost of the Jam}

The cost was based in the price of fruit pulp, sugar or xylitol and pectin. A container of $250 \mathrm{~g}$ was included in the calculation.

\subsection{Statistical Analysis}

The experiment of jam production was conducted in a completely randomized design, totaling eight treatments and three repetitions.

The data were submitted to the ANOVA e Tukey test at $5 \%$ probability $(\mathrm{p}<0.05)$. The statistical analyses were accomplished using the statistical program SISVAR version 5.3.

\section{Results and Discussion}

The soluble solids (SS), titratable acidity (TA) and $\mathrm{pH}$ of the umbu-caja pulps, at the green and ripe stages, from the Suprema and Preciosa accessions, are presented in Table 1. For jam production, those three components have technological importance since they influence the cooking time, and also the formation, structure, stability and continuity of the gel formed.

Previously, Ritzinger et al. [20] evaluated the TA and $\mathrm{SS}$ in these same accessions. The TA value of the ripe pulp of the Preciosa accession found in the present work is in agreement with the previous work, but the values for SS found in the two works are different. Ritzinger et al. [20] found SS mean values of $12.6^{\circ}$ Brix and $13.0^{\circ}$ Brix for the Suprema and Preciosa accessions, respectively.

The results of the physical and physicochemical characteristics of the manufactured jams are presented in Table 2. These results showed that the physicochemical characteristics of jams prepared with sucrose are close to the ones made with xylitol, except for the total sugars that influenced the energetic value. The low sugars content detected in the jam made with xylitol, processed from the fruit, results in a product low in calories.

The moisture content of the four formulations ranged from $26.27 \%$ to $31.98 \%$ (Table 2 ). These results were similar to those found in studies conducted by Lago [21] and Lago-Vanzela [22] in jambolão jam (29.6\%) and caja-manga jam (29.5\%), respectively. Mota [23] ob- served higher moisture contents $(42.8 \%$ to $46.4 \%)$ in jam made from different varieties of blackberries. It is important to consider that the moisture content is directly related to the conservation of the product during storage.

Conventional jam had SS value higher than the SS value of the dietetic jam due to sucrose use in conventional manufacture (Table 2). Folegatti et al. [24] found values for umbu jam ranging from $66.3^{\circ}$ Brix to $67.7^{\circ}$ Brix. Similar values were observed by Maciel et al. [25] in conventional mixed jelly of cherry and mango $\left(63.5^{\circ}\right.$ to $64.0^{\circ}$ Brix). Melo et al. [26] found higher levels of soluble solids, between $65^{\circ}$ to $73^{\circ}$ Brix in mixed jellies of acerola and cherry. According to CODEX [27] the soluble solids content of the finished jam should be between $65 \%$ or greater and the product should contain at least $45 \%$ fruit, being this results in accordance with this institution.

The $\mathrm{pH}$ values ranged from 2.42 to 2.92 and titratable acidity values ranged from 0.56 to 0.78 (Table 2). The values for the dietetic jams were close to the optimal values (around 3.2) for gel formation and consistency since values above 3.2 and below this value contribute for the obtainment of soft and hard jams, respectively. The concentration of hydrogen ion is important for geleification, and not the acidity. Therefore, the Preciosa Dietetic Ripe Pulp (PDRP) jam was the one that had the $\mathrm{pH}$ closest to the optimal $\mathrm{pH}$ in comparison to the values considered in the diagram of Rauch [28]; which ranges from 2.5 (hard jam) to 3.45 (soft jam). Folegatti et al. [24] found $\mathrm{pH}$ values ranging from 2.8 to 3.1 using $1 \%$ of calcium chloride according to the weight of the fruits, seeking to maintain the their strong texture.

Regarding the titratable acidity (TA), the values found ranged from 0.56 to 0.78 (Table 2). Values between $0.50 \%$ and $0.80 \%$ of citric acid are the optimal range values and above $1 \%$ cause sineresis, which is the exudation of the liquid of the jam. The results are close to the range of values found by Folegatti et al. [24] in umbu jam (0.62 to 0.88$)$.

For both accessions, the dietetic jams made from green or ripe pulp, showed a reduction of the caloric value between $91 \%$ and $92 \%$, in comparison to the conventional ones (Table 2). Yuyama et al. [11] in the dietetic jam of cubiu reached $97 \%$ of reduction in the energy value.

Table 1. Total soluble solids and titratable acidity, according to the accessions and ripening stages of the umbu-caja pulp.

\begin{tabular}{ccccc}
\hline \multirow{2}{*}{ Components } & \multicolumn{2}{c}{ Suprema } & \multicolumn{2}{c}{ Preciosa } \\
\cline { 2 - 5 } $\mathrm{pH}$ & Green pulp & Ripe pulp & Green pulp & Ripe pulp \\
\hline Soluble solids ('Brix) & $2.5 \pm 0.20^{\mathrm{a}}$ & $2.1 \pm 0.80^{\mathrm{b}}$ & $2.5 \pm 0.10^{\mathrm{a}}$ & $2.0 \pm 0.70^{\mathrm{b}}$ \\
Titratable acidity (\% citric acid) & $10.0 \pm 1.40^{\mathrm{a}}$ & $10.1 \pm 0.50^{\mathrm{a}}$ & $10.0 \pm 0.20^{\mathrm{a}}$ & $9.4 \pm 0.20^{\mathrm{b}}$ \\
\hline
\end{tabular}

Means followed by the same letters in the line do not statistically differ through the Tukey's test at $5 \%$ probaility, $n=3$. 
Table 2. Physiochemical characteristics of the umbu-caja jams, caloric value and cost.

\begin{tabular}{|c|c|c|c|c|c|c|c|c|}
\hline \multirow{3}{*}{ Components } & \multicolumn{4}{|c|}{ Suprema } & \multicolumn{4}{|c|}{ Preciosa } \\
\hline & \multicolumn{2}{|c|}{ Conventional } & \multicolumn{2}{|c|}{ Dietetic } & \multicolumn{2}{|c|}{ Conventional } & \multicolumn{2}{|c|}{ Dietetic } \\
\hline & Green pulp & Ripe pulp & Green pulp & Ripe pulp & Green pulp & Ripe pulp & Green pulp & Ripe pulp \\
\hline Humidity (\%) & $28.7 \pm 0.10^{\mathrm{bc}}$ & $28.2 \pm 0.20^{\mathrm{c}}$ & $28.2 \pm 0.20^{c}$ & $32.0 \pm 0.30^{\mathrm{a}}$ & $26.7 \pm 0.90^{\mathrm{d}}$ & $29.1 \pm 0.80^{\mathrm{bc}}$ & $29.7 \pm 0.40^{\mathrm{b}}$ & $29.0 \pm 0.40^{\mathrm{bc}}$ \\
\hline $\begin{array}{l}\text { Soluble solids } \\
\left.\text { ( }{ }^{\circ} \text { Brix }\right)\end{array}$ & $65.1 \pm 0.80^{\mathrm{a}}$ & $64.2 \pm 0.90^{\mathrm{abc}}$ & $62.8 \pm 0.10^{\text {bcd }}$ & $60.9 \pm 0.50^{\mathrm{d}}$ & $65.0 \pm 0.80^{\mathrm{ab}}$ & $63.3 \pm 0.10^{\mathrm{abc}}$ & $62.5 \pm 1.30^{\text {cd }}$ & $63.4 \pm 0.50^{\mathrm{abc}}$ \\
\hline $\begin{array}{l}\text { Total sugars } \\
\text { (\% glucose) }\end{array}$ & $56.9 \pm 0.50^{\mathrm{a}}$ & $52.5 \pm 1.70^{\mathrm{b}}$ & $4.5 \pm 0.10^{c}$ & $4.0 \pm 0.00^{\mathrm{c}}$ & $55.7 \pm 1.10^{\mathrm{a}}$ & $57.6 \pm 1.40^{\mathrm{a}}$ & $4.4 \pm 0.20^{\mathrm{c}}$ & $3.8 \pm 0.10^{\mathrm{c}}$ \\
\hline $\mathrm{pH}$ & $2.4 \pm 0.00^{\mathrm{g}}$ & $2.5 \pm 0.00^{\mathrm{e}}$ & $2.7 \pm 0.00^{c}$ & $2.7 \pm 0.00^{\mathrm{b}}$ & $2.4 \pm 0.00^{\mathrm{f}}$ & $2.4 \pm 0.00^{\mathrm{f}}$ & $2.6 \pm 0.00^{\mathrm{d}}$ & $2.9 \pm 0.00^{\mathrm{a}}$ \\
\hline $\begin{array}{l}\text { Titratable acidity } \\
\text { (\% citric acid) }\end{array}$ & $0.7 \pm 0.03^{\mathrm{a}}$ & $0.6 \pm 0.02^{\mathrm{d}}$ & $0.6 \pm 0.03^{\mathrm{c}}$ & $0.7 \pm 0.02^{\mathrm{ab}}$ & $0.7 \pm 0.00^{\mathrm{bc}}$ & $0.8 \pm 0.01^{\mathrm{a}}$ & $0.8 \pm 0.02^{\mathrm{a}}$ & $0.8 \pm 0.02^{\mathrm{a}}$ \\
\hline Ashes $(\%)$ & $0.3 \pm 0.01^{\mathrm{bc}}$ & $0.2 \pm 0.01^{\mathrm{cd}}$ & $0.2 \pm 0.01^{\mathrm{cd}}$ & $0.2 \pm 0.01^{\mathrm{ab}}$ & $0.3 \pm 0.00^{\mathrm{bc}}$ & $0.3 \pm 0.00^{\mathrm{ab}}$ & $0.2 \pm 0.01^{\mathrm{d}}$ & $0.3 \pm 0.00^{\mathrm{a}}$ \\
\hline Lipids (\%) & $0.1 \pm 0.00^{\mathrm{c}}$ & $0.1 \pm 0.00^{\mathrm{a}}$ & $0.1 \pm 0.00^{\mathrm{c}}$ & $0.1 \pm 0.00^{\mathrm{a}}$ & $0.1 \pm 0.00^{\mathrm{d}}$ & $0.1 \pm 0.00^{\mathrm{b}}$ & $0.1 \pm 0.00^{\mathrm{d}}$ & $0.1 \pm 0.00^{\mathrm{b}}$ \\
\hline Proteins (\%) & $0.5 \pm 0.03^{c}$ & $0.5 \pm 0.02^{\text {cd }}$ & $0.5 \pm 0.02^{\mathrm{d}}$ & $0.6 \pm 0.02^{\mathrm{ab}}$ & $0.6 \pm 0.01^{\mathrm{bc}}$ & $0.6 \pm 0.01^{\mathrm{a}}$ & $0.5 \pm 0.01^{\mathrm{cd}}$ & $0.5 \pm 0.01^{c}$ \\
\hline $\mathrm{L}^{*}$ & $20.0 \pm 0.00^{\mathrm{e}}$ & $24.7 \pm 0.00^{\mathrm{c}}$ & $25.1 \pm 0.50^{\mathrm{c}}$ & $27.6 \pm 0.00^{\mathrm{a}}$ & $23.9 \pm 0.00^{\mathrm{d}}$ & $24.7 \pm 0.00^{\mathrm{c}}$ & $24.2 \pm 0.00^{\mathrm{d}}$ & $26.1 \pm 0.1^{b}$ \\
\hline$a^{*}$ & $0.6 \pm 0.00^{\mathrm{d}}$ & $1.0 \pm 0.00^{\mathrm{bc}}$ & $1.3 \pm 0.10^{\mathrm{a}}$ & $0.7 \pm 0.00^{\mathrm{d}}$ & $1.1 \pm 0.10^{\mathrm{ab}}$ & $0.9 \pm 0.10^{c}$ & $1.1 \pm 0.10^{\text {cd }}$ & $1.0 \pm 0.00^{\mathrm{bc}}$ \\
\hline $\mathrm{b}^{*}$ & $4.4 \pm 0.00^{\mathrm{a}}$ & $3.9 \pm 0.00^{\mathrm{b}}$ & $3.2 \pm 0.10^{\mathrm{e}}$ & $3.6 \pm 0.00^{\mathrm{c}}$ & $3.1 \pm 0.00^{\mathrm{e}}$ & $4.0 \pm 0.00^{\mathrm{b}}$ & $3.4 \pm 0.00^{\mathrm{d}}$ & $3.5 \pm 0.00^{\mathrm{c}}$ \\
\hline $\mathrm{C}^{*}$ & $4.44 \pm 0.00^{\mathrm{a}}$ & $4.0 \pm 0.00^{\mathrm{b}}$ & $3.4 \pm 0.10^{\mathrm{d}}$ & $3.6 \pm 0.00^{\mathrm{c}}$ & $3.3 \pm 0.00^{\mathrm{d}}$ & $4.1 \pm 0.00^{\mathrm{b}}$ & $3.6 \pm 0.00^{\mathrm{c}}$ & $3.7 \pm 0.00^{\mathrm{c}}$ \\
\hline $\mathrm{h}^{*}$ & $81.40 \pm 0.50^{\mathrm{a}}$ & $75.5 \pm 0.40^{\mathrm{cd}}$ & $68.5 \pm 1.70^{\mathrm{e}}$ & $78.9 \pm 0.20^{\mathrm{ab}}$ & $70.1 \pm 0.80^{\mathrm{e}}$ & $77.0 \pm 0.80^{\mathrm{bc}}$ & $72.9 \pm 1.30^{\mathrm{d}}$ & $74.3 \pm 0.50^{\mathrm{cd}}$ \\
\hline Firmness (g) & $172.33 \pm 0.00^{\mathrm{h}}$ & $244.5 \pm 0.00^{\mathrm{g}}$ & $270.1 \pm 0.00^{\mathrm{b}}$ & $257.9 \pm 0.00^{\mathrm{c}}$ & $254.3 \pm 0.00^{\mathrm{e}}$ & $329.0 \pm 0.00^{\mathrm{a}}$ & $248.2 \pm 0.00^{\mathrm{f}}$ & $257.7 \pm 0.00^{\mathrm{d}}$ \\
\hline $\begin{array}{l}\text { Consistency } \\
\left(\mathrm{g} \cdot \mathrm{seg}^{-1}\right)\end{array}$ & $646.26 \pm 0.00^{\mathrm{h}}$ & $792.8 \pm 0.00^{\mathrm{e}}$ & $890.0 \pm 0.00^{\mathrm{b}}$ & $739.9 \pm 0.00^{\mathrm{f}}$ & $713.4 \pm 0.00^{\mathrm{g}}$ & $907.8 \pm 0.00^{\mathrm{a}}$ & $810.0 \pm 0.00^{\mathrm{d}}$ & $821.5 \pm 0.00^{\mathrm{c}}$ \\
\hline $\begin{array}{l}\text { Caloric value } \\
\text { (Kcal/100 g) }\end{array}$ & $230.2 \pm 0.40^{\mathrm{a}}$ & $212.9 \pm 0.02^{\mathrm{b}}$ & $20.4 \pm 0.50^{\mathrm{c}}$ & $19.2 \pm 0.10^{\mathrm{c}}$ & $225.7 \pm 0.10^{\mathrm{a}}$ & $233.5 \pm 0.40^{\mathrm{a}}$ & $20.3 \pm 0.10^{\mathrm{c}}$ & $18.3 \pm 0.60^{\mathrm{c}}$ \\
\hline Cost (U\$) & $1.10^{*}$ & $1.10^{*}$ & $6.45^{*}$ & $6.45^{*}$ & $1.10^{*}$ & $1.10^{*}$ & $6.45^{*}$ & $6.45^{*}$ \\
\hline
\end{tabular}

Means followed by the same letters in the line do not statistically differ through the Tukey's test at $5 \%$ probability; $\mathrm{n}=3$.

Nachtigall et al. [6] worked with blackberry light jams and verified a reduction between $46.3 \%$ and $47.6 \%$ when sucralose was used. Granada et al. [29] observed reducetion from $33.5 \%$ to $36.6 \%$ in pineapple light jams made with sucralose. Barcia et al. [11] found reduction in the caloric value ranging from $25.9 \%$ to $37.9 \%$ in jambolão fruit jams using four types of sweeteners in an isolated and combined way (saccharin, cyclamate, acesulfame and stevioside).

In agreement Brazilian Agency of Sanitary Surveillance [30,31], the term light is used for foods with reduced caloric value, being the minimum $25 \%$ of the conventional product, and the term diet is applied to foods especially formulated or processed, suitable for use in diets, assisting the people's needs in specific metabolic and physiologic conditions. Therefore, the jams that used xylitol can be denominated as diet and can be recommended for individuals with restriction of sugars.

The color is an important visual quality of food products. The values obtained for $\mathrm{L}^{*}$ coordinate, ranged from
20.0 to 27.64 , characterizing darker colors, once $\mathrm{L}^{*}$ ranges from zero (pure black) to one-hundred (pure white). The jams manufactured with sucrose had lower $\mathrm{L}^{*}$ values than the ones made with xylitol. This fact can be explained due to the caramelization of sugars and consequently formation of hydroxymethylfurfural (HMF), which is often an intermediate product, being able to undergo polymerization, producing melanin, darkening the product. These values were below to the ones found by Martins et al. [32], working with sweets in mass of green and ripe umbu (40.2 to 48 and 42.2 to 42.9 , respectively).

The values of $a^{*}$ obtained for all treatments were positive, which suggests a color variation towards red, however, with little intensity. Martins et al. [32] also found positive values (6.9 to 8.6) to umbu marmalades.

The $b^{*}$ values was situated in a strip ranging from 3.1 to 4.39 , indicating higher tendency toward yellowish tones due to the higher $\mathrm{b}^{*}$ values over the $\mathrm{a}^{*}$ component. For the sweet in mass of green and ripe umbu, Martins et 
al. [32] also found superiority of the yellow tones, with values between 21.4 to 23.6 and 19.20 to 20.8 , respectively. The conventional jams had higher values of chromaticity $\left(\mathrm{C}^{*}\right)$, which means cleaner colors, except for the accession Preciosa made with green pulp (Table 2). The color angle $\left(\mathrm{h}^{*}\right)$ ranged from $68.5^{\circ}$ to $81.4^{\circ}$, indicating proximity to yellowish tones $\left(90^{\circ}\right)$.

The firmness for the jams varied from $172.33 \mathrm{~g}$ to $329.0 \mathrm{~g}$, and the consistency between $646.26 \mathrm{~g} \cdot \mathrm{seg}^{-1}$ and $907.8 \mathrm{~g} \cdot \mathrm{seg}^{-1}$, as presented in Table 2 . The variation in the force values observed between the samples indicated differences in the structure of the gel of the products due to the variability of $\mathrm{pH}$ and of the formulations; a conventional (sucrose) and a dietetic (xylitol). Values of firmness were close to those obtained by Godoy et al. [33], varying from $75.1 \mathrm{~g}$ to $306.1 \mathrm{~g}$ for commercial banana paste products. The gel structure of jam is due to sugar/ pectin/acid interactions. Although there is not sucrose present in the dietetic jam, xylitol has contributed to the gel formation, since xylitol has five hydroxyls in its chemical structure, facilitating the formation of a threedimensional net (gel). According to Saha and Bhattacharya [34], for the pectin with high methoxyl content (HMC), the geleification mechanism is achieved by hydrogen bonds. The pectins are the most preferred gelling agents for acidic fruit gels because of being acid stable $[35,36]$. Xylitol as well as sucrose have free hydroxyls that can make connections of hydrogen with the pectin $\mathrm{HMC}$.

The cost of jam made with xylitol was $83.3 \%$ higher than that made with sucrose. This cost difference can be explained by the fact that xylitol is an ingredient more expensive than sucrose.

The results of acceptance test are presented in Table 3. The grades averaged from 6.98 to 7.74 (appearance); 6.88 to 7.48 (color); 5.90 to 7 (aroma). The Preciosa Diet Green Pulp (PDGP) presented the highest scores in appearance (7.74) and color (7.60). According to Meilgaard et al. [16], vision is the only aspect in which the consumer uses as a base for the action of purchase. The highest score to aroma was observed in the Suprema Diet Ripe Pulp (7) (SDRP) which differed significantly from Preciosa Conventional Green Pulp (5.9). The consumers evaluated the aroma or the jams made with ripe and green pulp in similar way, besides Narain et al. [2] considers that ripe fruit has higher concentration of volatile compounds that contribute to the aroma.

The sensorial tests showed that the dietetic and the conventional jams have similar flavors and texture $(\mathrm{p}>$ 0.05). Therefore, the market could offer consumers of diet jam a product without sugar and with identical flavor as the product made with sucrose.

Yuyama et al. [11] obtained an acceptability of $85.62 \%$ for the cubiu jam made with xylitol and $81.05 \%$ for the jams with sucrose. The authors verified that there was no significant difference at the 5\% level, confirming the similarity between the jams. Singh et al. [37] found lower scores for appearance (5.7), flavor (5.7), color (5.3) and texture (5.3) in the pineapple jam made with sucrose, using a nine-point scale.

The results of purchasing intention showed that the conventional jams, no matter the access and maturity, had the highest purchase intention (Figure 1). Through the addition of categories 1 ("Definitely would buy") and 2 ("Probably would buy"), it is shown that $22 \%$ to $44 \%$ of consumers would buy the Preciosa conventional Ripe Pulp, if this were commercialized. For the preciosa Dietetic Ripe Pulp, $26 \%$ to $38 \%$ of consumers expressed their intention to purchase the product. Considering the percentage of the population who consume diet foods, this result highlights a potential market for both types of jam developed as well to attend a population group with restrictions on use of sucrose, in search of this type of product.

\section{Conclusions}

The fruit of umbucajazeira showed to be promising for jam production.

The use of xylitol in the manufacture of umbu-caja

Table 3. Acceptance test of umbu-caja jams.

\begin{tabular}{|c|c|c|c|c|c|c|c|c|}
\hline \multirow{3}{*}{ Components } & \multicolumn{4}{|c|}{ Suprema } & \multicolumn{4}{|c|}{ Preciosa } \\
\hline & \multicolumn{2}{|c|}{ Conventional } & \multicolumn{2}{|c|}{ Diet } & \multicolumn{2}{|c|}{ Conventional } & \multicolumn{2}{|c|}{ Diet } \\
\hline & Green pulp & Ripe pulp & Green pulp & Ripe pulp & Green pulp & Ripe pulp & Green pulp & Ripe pulp \\
\hline Appearance & $6.9^{\mathrm{b}}$ & $7.3^{\mathrm{ab}}$ & $7.0^{\mathrm{ab}}$ & $7.4^{\mathrm{ab}}$ & $7.1^{\mathrm{ab}}$ & $7.2^{\mathrm{ab}}$ & $7.7^{\mathrm{a}}$ & $7.0^{\mathrm{ab}}$ \\
\hline Color & $6.8^{\mathrm{b}}$ & $7.2^{\mathrm{ab}}$ & $6.9^{\mathrm{ab}}$ & $7.5^{\mathrm{ab}}$ & $7.3^{\mathrm{ab}}$ & $7.2^{\mathrm{ab}}$ & $7.6^{\mathrm{a}}$ & $7.4^{\mathrm{ab}}$ \\
\hline Aroma & $6.5^{\mathrm{abc}}$ & $6.7^{\mathrm{ab}}$ & $6.2^{\mathrm{bc}}$ & $7.0^{\mathrm{a}}$ & $5.9^{\mathrm{c}}$ & $6.4^{\mathrm{abc}}$ & $6.7^{\mathrm{ab}}$ & $6.8^{\mathrm{ab}}$ \\
\hline Flavor & $7.2^{*}$ & $7.0^{*}$ & $6.4^{*}$ & $6.7^{*}$ & $6.8^{*}$ & $6.7^{*}$ & $6.5^{*}$ & $6.6^{*}$ \\
\hline Texture & $7.2^{*}$ & $7.3^{*}$ & $6.8^{*}$ & $7.1^{*}$ & $6.8^{*}$ & $6.7^{*}$ & $6.9^{*}$ & $7.2^{*}$ \\
\hline
\end{tabular}

Means followed by the same letters in the line do not statistically differ through the Tukey's test at $5 \%$ probability; ${ }^{*}$ not significant; $\mathrm{n}=50$ consumers. 


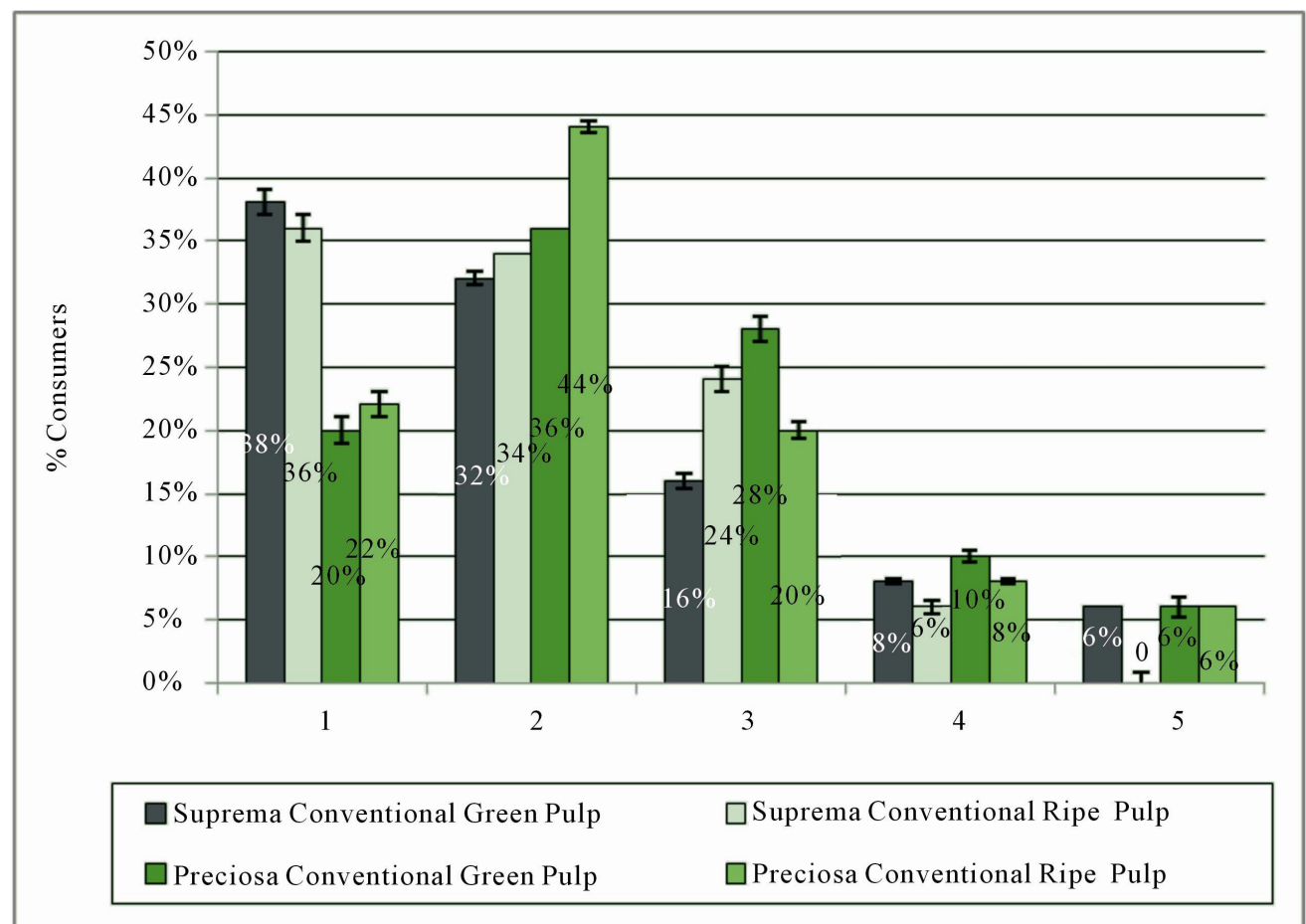

(a)

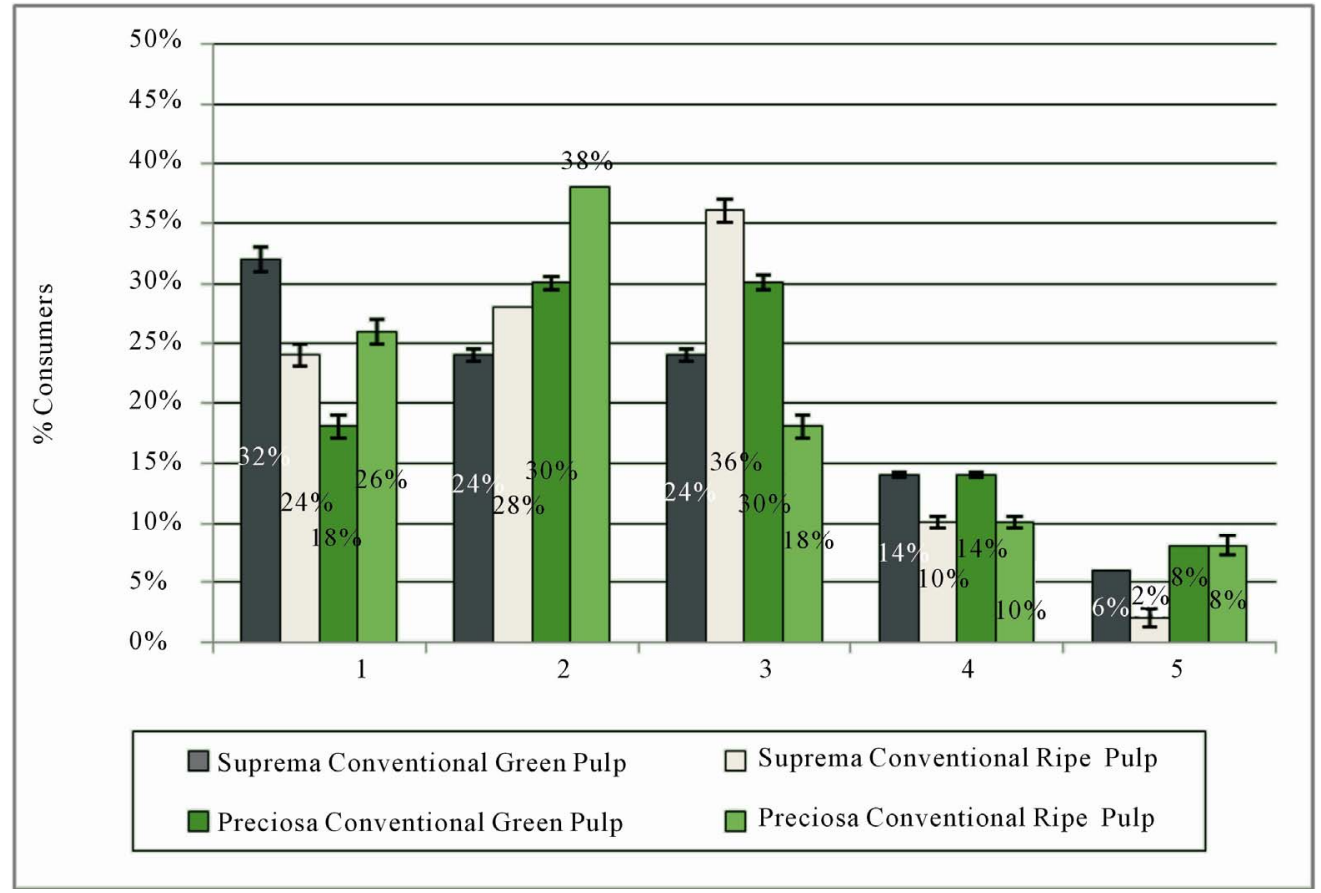

(b)

Figure 1. Percentage of consumers due to the purchasing intention for the umbu-caja jams made with green and ripe pulps. (a) Conventional Jam; (b) Dietetic Jam. Numbers 1, 2, 3, 4, 5 on x-axis indicate: Definitely would buy, Probably would buy, Maybe/maybe not would buy, Probably would not buy it, Definitely would not buy, respectively. $n=50$ consumers.

jam was shown to be satisfactory, resulting in a product with jam characteristics and with flavor and texture similar to conventional jam, with low caloric value, allowing its indication as much for diabetics as to the individuals that are on a diet with caloric restriction. The jam conventional and diet, manufactured with both accessions, sweetened with sucrose or xylitol presented a good acceptance, considering all attributes evaluated and 
purchase intention. This product has a market potential, guaranteeing aggregation of value to the processed fruit of the umbucajazeira.

\section{Acknowledgements}

The authors would like to thank the Tovani Benzaquen Com. Imp. Exp. e Representações LTDA, for donating the xylitol used in the pre tests. And the Coordenação de Aperfeiçoamento de Pessoal de Nível Superior (CAPES) for the financial support.

\section{REFERENCES}

[1] P. C. L. Carvalho, R. Ritzinger, W. S. Soares-Filho, C. A. S. Ledo, "Morphological, Physical and Chemical Characteristics of Fruits of Umbu-Cajazeira Populations in the State of Bahia," Revista Brasileira de Fruticultura, Vol. 30, No. 1, 2008, pp. 140-147. doi:10.1590/S0100-29452008000100026

[2] N. Narain, M. S. Galvão and S. M. Madruga, "Volatile Compounds Captured through Purge and Trap Technique in Cajá-Umbu (Spondias sp.) Fruits during Maturation," Food Chemistry, Vol. 102, No. 3, 2007, pp. 726-731. doi:10.1016/j.foodchem.2006.06.003

[3] E. D. P. A. Lima, C. A. A. Lima, M. L. Aldrigue and P. J. S. Gondim, "Physical and Chemical Characterization on the Fruits of Umbu-Cajazeira (Spondias spp.) in Five Ripening Stages, Frozen Pulp and Nectar," Revista Brasileira de Fruticultura, Vol. 24, No. 2, 2002, pp. 338-343. doi:10.1590/S0100-29452002000200013

[4] M. I. S. Maciel and I. C. S. Guerra, "Usos e Aplicações de Spondias: Processamento e Industrialização,” In: I. E. Lederman, J. S. Lira Junior and J. F. Silva Junior, Eds., Spondias No Brasil: Umbu, Cajá e Espécies Afins, IPA, Recife, 2008, pp. 167-173.

[5] Instituto Brasileiro de Frutas. http://www.ibraf.org.br/estatisticas/Export_Processadas/C om-tivo_Exportacoes_Brasileiras_Frutas_Processadas_20 08-2007.pdf Accessed 22 February 2010

[6] A. Abdullah and C. T. Cheng, "Optimization of Reduced Calorie Tropical Mixed Fruits Jam," Food Quality and Preference, Vol. 12, No. 1, 2001, pp. 63-68. doi:10.1016/j.foodqual.2007.06.010

[7] A. M. Nachtigall, E. L. Souza, M. B. Malgarim and R. C. Zambiazi, "Blackberry Light Jams," Boletim do Centro Pesquisa e Processamento de Alimentos, Vol. 22, No. 2, 2004, pp. 337-354.

[8] A. M. Nachtigall and R. C. Zambiazi, "Hibiscus Jams with Reduced Caloric Content: Sensorial Characteristics," Boletim do Centro de Pesquisa e Processamento de Alimentos, Vol. 24, No. 1, 2006, pp. 47-58.

[9] R. V. Mota, "Chemical Characterization and Acceptability of Blackberry Low Soluble Solids Jams," Brazilian Journal of Food Technology, Vol. 10, No. 2, 2007, pp. 116-121.

[10] A. F. R. Silva and R. C. Zambiazi, "Acceptability of Conventional and Light Pineapple Jams Obtained from Agro- industrial Residues," Boletim do Centro de Pesquisa e Processamento de Alimentos, Vol. 26, No. 1, 2008, pp. 1-8.

[11] L. K. O. Yuyama, L. Pantoja, R. N. Maeda, J. P. L. Aguiar and S. B. Silva, "Development and Acceptability of a Low Calorie Cubiu (Solanum sessiliflorum Dunal) Jam," Ciência e Tecnologia de Alimentos, Vol. 28, No. 4, 2008, pp. 929-934. doi:10.1590/S0101-20612008000400026

[12] M. T. Barcia, A. L. Medina and R. C. Zambiazi, "Physico-Chemical and Sensory Characteristics of Jambolão Jams," Boletim do Centro de Pesquisa e Processamento de Alimentos, Vol. 28, No. 1, 2010, pp. 25-36.

[13] Agência Nacional de Vigilância Sanitária, ResoluçãoRDC No. 360, 2003.

http://www.anvisa.gov.br/legis/resol/2003/rdc/360_03rdc. htm Accessed 13 march 2010a

[14] O. R. Fennema, S. Damodaram and K. L. Parkin, "Fennema's Food Chemistry," 4th Edition, Artmed, Porto Alegre, 2010.

[15] S. Chattopadhyay, U. Raychaudhuri and R. Chakraborty, "Artificial Sweeteners-A Review," Journal of Food Science and Technology, 2011. doi:10.1007/s13197-011-0571-1

[16] M. Meilgaard, G. V. Civille and B. T. Carr, "Sensory Evaluation Techniques," 4th Edition, CRC Press, Boca Raton, 2007.

[17] IAL, "Normas Analíticas do Instituto Adolfo Lutz. Métodos Químicos e Físicos Para Análise de Alimentos," 4th Edition, Instituto Adolfo Lutz, São Paulo, 2005.

[18] N. Nelson, "A Photometric Adaptation of the Somogyi Method for the Determination of Glucose," The Journal of Biological Chemistry, Vol. 153, No. 2, 1944, pp. 375380.

[19] M. Somogyi, "A New Reagent for the Determination of Sugar," The Journal of Biological Chemistry, Vol. 160, No. 1, 1945, pp. 61-68.

[20] R. Ritzinger, W. S. Soares Filho and M. S. Castellen, "Coleção de Spondias spp. da Embrapa Mandioca e Fruticultura Tropical,” In: I. E. Lederman, J. S. Lira Junior and J. F. Silva Junior, Eds., Spondias No Brasil: Umbu, Cajá e Espécies Afins, IPA, Recife, 2008, pp. 86-90.

[21] E. S. Lago, E. Gomes and R. Silva, "Production of Jambolan (Syzygium cumini Lamarck) Jelly: Processing, Physical-Chemical Properties and Sensory Evaluation," Ciência e Tecnologia de Alimentos, Vol. 26, No. 4, 2006, pp. 847-852. doi:10.1590/S0101-20612006000400021

[22] E. S. Lago-Vanzela, P. Ramin, M. A. Guez-Umsza, G. V. Samtps, E. Gomes and R. da Silva, "Chemical and Sensory Characteristics of Pulp and Peel Cajá-Manga (Spondias cytherea Sonn.) Jelly," Ciência e Tecnologia de Alimentos, Vol. 31, No. 2, 2011, pp. 398-405. doi:10.1590/S0101-20612011000200018

[23] R. V. Mota, "Physico and Chemical Characterisation of Blackberry Jam," Ciência e Tecnologia de Alimentos, Vol. 26, No. 3, 2006, pp. 539-543. doi:10.1590/S0101-20612006000300009

[24] M. I. S. Folegatti, F. C. A. U. Matsuura, R. L. Cardoso, S. S. Machado, A. S. Rocha and R. R. Lima, "Industrial Use of Umbu: Jam and Fruit-in-Syrup Processing," Ciência e 
Agrotecnologia, Vol. 27, No. 6, 2003, pp. 1308-1314.

[25] M. I. S. Maciel, E. A. Melo, V. L. A. G. de Lima, W. S. da Silva, C. M. C. Maranhão and K. A. de Souza, "Sensory and Physico-Chemical Characterizations of Mixed Mango and Acerola Jam," Boletim do Centro de Pesquisa e Processamento de Alimentos, Vol. 27, No. 2, 2009, pp. 247-256.

[26] E. A. Melo, V. L. A. G. Lima and P. P. Nascimento, "Formulations and Evaluations Physicochemical and Sensory Analysis of Jam Were Prepared with a Mix of Surinan Cherry (Eugenia uniflora L.) and Acerola (Malpighia sp.)," Boletim do Centro de Pesquisa e Processamento de Alimentos, Vol. 17, No. 1, 1999, pp. 33-44.

[27] CODEX, "Codex Standard 296: Standard for Jams," Jellies and Marmalades, 2009. http://www.codexalimentarius.net

[28] G. H. Rauch, "Jam Manufacture," Leonard Hill Books, London, 1965.

[29] G. G. Granada, R. C. Zambiazi, C. R. B. Mendonca and E. Silva, "Physical, Chemical, Microbiological and Sensory Characterization of Light Jams of Pineapple," Ciência e Tecnologia de Alimentos, Vol. 25, No. 4, 2005, pp. 629635. doi:10.1590/S0101-20612005000400002

[30] Agência Nacional de Vigilância Sanitária, Portaria SVS/ MS 27, 1998.

http://e-legis.anvisa.gov.br/leisref/public/showAct.php?id $=97$ Accessed 26 march $2010 \mathrm{~b}$

[31] Agência Nacional de Vigilância Sanitária, Portaria SVS/ MS 29, 1998.

http://e-legis.anvisa.gov.br/leisref/public/showAct.php?id
$=17213 \&$ word $=$ Accessed 13 march $2010 \mathrm{c}$

[32] M. L. A. Martins, S. V. Borges, R. Deliza, F. T. Castro and N. B. Cavalcante, "Characteristics of Green and Ripe Umbu Marmalades and Acceptance by Consumers," Pesquisa Agropecuária Brasileira, Vol. 42, No. 9, 2007, pp. 1329-1333. doi:10.1590/S0100-204X2007000900015

[33] R. C. B. Godoy, E. L. S. Matos, D. V. Santos, T. S. Amorim, N. Waszczynskyj and M. A. Sousa-Neto, "Study on Physical-Chemical Composition and Acceptance of Marketed Banana Jams by Means of Multivariate Analysis," Revista do Instituto Adolfo Lutz, Vol. 68, No. 3, 2009, pp. 373-380.

[34] D. Saha and S. Bhattacharya, "Hydrocolloids as Thickening and Gelling Agents in Food: A Critical Review," Journal of Food Science and Technology, Vol. 47, No. 6, 2010, pp. 587-597.

[35] M. S. Lima, E. P. Paiva, S. A. C. Andrade and J. A. Paixao, "Fruit Pectins-A Suitable Tool for Screening Gelling Properties Using Infrared Spectroscopy," Food Hydrocolloid, Vol. 24, No. 1, 2010, pp. 1-7. doi:10.1016/i.foodhyd.2009.04.002

[36] D. Dhingra, M. Michael, H. Rajput and R. T. Patil, "Dietary Fibre in Foods: A Review," Journal of Food Science and Technology, Vol. 49, No. 3, 2012, pp. 255-266.

[37] S. Singh, S. Jain, S. P. Singh and D. Singh, "Quality Changes in Fruit Jams from Combinations of Different Fruit Pulps," Journal of Food Processing and Preservation, Vol. 33, No. 1, 2009, pp. 41-57. doi:10.1111/j.1745-4549.2008.00249.x 